\title{
Common mycelium network of mycorrhizas alters plant biomass and soil properties between trifoliate orange seedlings
}

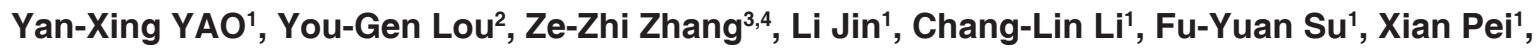 \\ Qiang-Sheng $\mathbf{W u}^{3,4}$, Shou-Kun Yang ${ }^{1 *}$ \\ ${ }^{1}$ Wuhan Forestry \& Fruit Tree Research Institute, Wuhan, Hubei 430075, China; ${ }^{2}$ School of Foreign Studies, Yangtze University, Jingzhou, \\ Hubei 434025, China; ${ }^{3}$ College of Horticulture and Gardening, Yangtze University, Jingzhou, Hubei 434025, China; ${ }^{4}$ Institute of Root Biology, \\ Yangtze University, Jingzhou, Hubei 434025, China
}

\section{A B S T R A C T}

\begin{abstract}
Common mycelium networks (CMNs) of arbuscular mycorrhizas link neighbour plants and thus exhibit important roles in underground communication of substances between plants. In this study, a two-compartmented rootbox separated by 37- $\mu \mathrm{m}$ (mycelium, but not root, can pass through the size mesh) or $0.45-\mu \mathrm{m}$ (both mycelium and root can't pass through the size mesh) mesh was used, where one compartment was inoculated with Paraglomus occultum. We confirmed whether CMNs establish between trifoliate orange seedlings and have the roles in improving both plant growth and soil properties in receptor plant (the plant inoculated without mycorrhizal fungi but infected by mycorrhizal mycelium of another inoculated plant). A CMN was formed between trifoliate orange seedlings under separation of $37-\mu \mathrm{m}$ but not $0.45-\mu \mathrm{m}$ mesh, resulting in a moderate root colonization of receptor plant. The mycorrhizal inoculation significantly increased leaf, stem, and root fresh weight and rhizospheric three glomalin-related soil protein (GRSP) concentrations, soil organic carbon, and mean weight diameter in the donor plant (the inoculated plant with mycorrhizal fungi). The CMN under 37- $\mu \mathrm{m}$ mesh condition had significantly positive effects on the above growth and soil properties in the receptor plant. Under $0.45-\mu \mathrm{m}$ mesh, the AMF inoculation in donor plant considerably inhibited biomass production of receptor plant, but increased easily-extractable GRSP, total GRSP, soil organic carbon, and mean weight diameter in receptor plant. It suggested that AMF inoculation and the subsequent CMN establishment would benefit improvement of plant growth and soil aggregation and fertility in donor and receptor plant.
\end{abstract}

Keywords: Aggregate stability; Extraradical hyphae; Glomalin; Mycorrhiza; Rootbox

\section{INTRODUCTION}

Arbuscular mycorrhizal fungi (AMF), one of soil inhabited microorganisms, can colonize roots of $\sim 80 \%$ land's plants to form a beneficial association, viz., arbuscular mycorrhizas (AMs) (Smith and Read, 2008). The AMs accelerate metabolism of host plants (Schweiger and Muller, 2015; Wu et al., 2013b, 2015b) and also change physical and chemical properties in plants and soil (Wang et al., 2014; Wu et al., 2014b, 2015a). Extraradical mycorrhizal mycelium as a part of mycorrhizas show fast and random growth, and can colonize the neighbor plants for the establishment of a common mycelium network (CMN) (Walder et al., 2012). The CMN can exchange nutrients and signaling between plants (Southworth et al.,
2005; Meding and Zasoki, 2008; Bainard et al., 2011; Buscardo et al., 2014). The study conducted by Cruz et al. (2003) revealed that CMN induced by Gigaspora margarita could be established between papaya (Carica papaya) and bahiagrass (Paspalum notatum) plants. Various nutrients, such as $\mathrm{P}, \mathrm{C}, \mathrm{N}$ and As, were communicated by the $\mathrm{CMN}$ between plants (Tuffen et al., 2002; Nakano-Hylander and Olsson, 2007; Meding and Zasoki, 2008). As a result, soil CMN had the functioning for healthy growth of the receptor plants (Barto et al., 2012).

Soil aggregation, as an ecological variable, strongly affects the global climate and soil degradation, gas exchanging, and nutrient cycling (Piotrowski et al., 2004). Soil aggregate stability depends on a number of biological factors,

\footnotetext{
${ }^{*}$ Corresponding author:

Shou-Kun Yang, Senior Engineer working in Wuhan forestry and fruit tree research institute, Hubei Province, China, Study on the physiology of Citrus in the beginning of 1987. E-mail: 196737649@qq.com

Received: 10 September 2015;

Revised: 17 January 2016;

Accepted: 18 January 2016;

Published Online: 15 February 2016
} 
including fungal hyphae, microbial biomass, root systems, input of $\mathrm{C}$ and $\mathrm{N}$ from fresh matrix, and aromatic humic substances (García-Orenes et al., 2012 ). Mycorrhizal hyphae can enwind soil aggregates and thus play a vital role in forming and stabilizing soil aggregates (García-Orenes et al., 2012; Peng et al., 2013). In addition, mycorrhizal hyphae secrete a special glyprotein, glomalin, into soils defined as glomalin-related soil protein (GRSP) (Wang et al., 2014; Wu et al., 2012, 2014a). GRSP improved soil structure, reduced degradation of soil organic matter, and increased carbon sequestration in soil (Rillig, 2004; Wu et al., 2008). AMF inoculation not only improved soil aggregate distribution at the size of $1-2 \mathrm{~mm}$, but also considerably increased soil organic carbon (SOC) and GRSP level (Wu et al., 2014b). Wang et al. (2014) observed that different AMF species had different effects on aggregate stability.

Trifoliate orange (Poncirus trifoliata L. Raf.), a close Citrus species, is widely used as a citrus rootstock and strongly dependent on AMs. In orchard, lots of citrus trees are neighbors, whereas it is not known whether $\mathrm{CMN}$ formed between citrus plants. In this study, we made a twochambered rootbox to simulate a CMN and thus confirmed whether CMN could establish between trifoliate orange seedlings and $\mathrm{CMN}$ had the roles in increasing plant growth and improving soil properties in receptor plant.

\section{MATERIALS AND METHODS}

\section{Two-chambered rootbox preparation}

The studied rootbox was made of plexiglass, whose length, width and height were $18.5,12$, and $16 \mathrm{~cm}$, respectively. The rootbox was divided into two equal compartments by $37-\mu \mathrm{m}$ or $0.45-\mu \mathrm{m}$ nylon mesh. Meanwhile, 37- $\mu \mathrm{m}$ nylon mesh can allow mycorrhizal extraradical hyphae, but not plant roots, to enter another compartment, and 0.45- $\mathrm{m}$ nylon mesh can't allow both mycorrhizal hyphae and plant roots to enter another compartment. In the rootbox, an air gap $(1.5 \mathrm{~cm}$ width) was created in the center of rootbox using two layers of nylon mesh to reduce diffusion of substances between the two compartments.

\section{Plant culture}

Seeds of trifoliate orange were disinfected with $70 \%$ alcohol for $5 \mathrm{~min}$, washed with distilled water, and germinated in autoclaved $\left(121^{\circ} \mathrm{C}, 0.11 \mathrm{Mpa}, 1.5 \mathrm{~h}\right)$ sands in $26^{\circ} \mathrm{C}$ and $16: 8$ photoperiod. Two four-leaf-old trifoliate orange seedlings without mycorrhization were transplanted into each compartment of the two-chambered rootbox. The 1,500 g soil (Xanthi-Udic Ferralsol, FAO system) was supplied into each chamber. The soil collected from a citrus orchard of Yangtze University campus $\left(30^{\circ} 36^{\prime} \mathrm{N}, 112^{\circ} 14^{\prime} \mathrm{E}\right)$ was air-dried, sieved $(4 \mathrm{~mm})$, and autoclaved with $121^{\circ} \mathrm{C}$ and $0.11 \mathrm{Mpa}$ for $1.5 \mathrm{~h}$.

Approximately 1,500 spores of Paraglomus occultum (C. Walker) J.B. Morton \& D. Redecker were applied into the designed chamber of the rootbox, where the inoculated trifoliate orange was regarded as the donor, and the seedlings from the other chamber of the same rootbox was designed as the receptor. Non-AMF inoculated treatment received same amount of autoclaved $\left(121^{\circ} \mathrm{C}, 0.11 \mathrm{Mpa}\right.$, $1.5 \mathrm{~h}$ ) inocula plus $2 \mathrm{~mL}$ inoculum filtrate ( $25 \mu \mathrm{m}$ filter) to keep similar microbial communities except the AM fungus. The spores of this strain were obtained from the Bank of Glomeromycota in China and propagated with white clover as a host plant for 12 weeks under potted conditions.

The experiment consisted of three treatments: (1) Each chamber of the rootbox under separation 37- $\mu \mathrm{m}$ mesh condition did not receive the AMF inoculation $\left(\mathrm{TO}^{-}\right.$ $/ 37 \mu \mathrm{m} / \mathrm{TO}^{-}$); (2) One chamber of the rootbox only received AMF inoculation as donor plant, and the two chambers of the rootbox were separated by $37-\mu \mathrm{m}$ mesh $\left(\mathrm{TO}^{+} / 37 \mu \mathrm{m} / \mathrm{TO}^{-}\right)$; (3) One chamber of the rootbox only received AMF inoculation as donor plant, and the two chambers of the rootbox were separated by $0.45-\mu \mathrm{m}$ mesh $\left(\mathrm{TO}^{+} / 0.45 \mu \mathrm{m} / \mathrm{TO}^{-}\right)$. Each treatment had four replicates with the completely randomized arrangement, resulting in a total of 12 rootboxes.

The experiment was performed during March 28 - August 16, 2014 in a glass house, where photon flux density is $880 \mu \mathrm{mol} \mathrm{m} \mathrm{m}^{-2} \mathrm{~s}^{-1}$, day/night temperature $28 / 21^{\circ} \mathrm{C}$, and relative air humidity $85 \%$.

\section{Variable determinations}

At harvest, the seedlings from each chamber of the rootbox were divided into leaf, stem, and root, whose fresh weight was measured.

Root mycorrhizas were stained according to the protocol of Phillips and Hayman (1970). Root AM colonization was calculated as the percentage of AM colonized root length against total root length. Soil hyphal length was measured according to the procedure of Bethlenfalvay and Ames (1987). Glomalin-related soil protein (GRSP) fractions, including easily-extractable glomalin-related soil protein (EE-GRSP) and difficultly-extractable glomalin-related soil protein (DE-GRSP), were extracted and measured following the protocol as described by Wu et al. (2014a; 2015a). Total glomalin-related soil protein (T-GRSP) is the sum of EEGRSP and DE-GRSP. SOC content was determined by the dichromate oxidation spectrophotometric method (Rowell, 1994). Mean weight diameter (MWD) was expressed as soil aggregate stability (Kemper and Rosenau, 1986). 
Distribution of water-stable aggregates at the size of $0.25-0.5,0.5-1,1-2$, and $2-4 \mathrm{~mm}$ was determined using wet-sieving procedure, and then MWD was calculated by the following formula: MWD $=\sum_{i=1}^{n} W i X i$, where $n, W i$, and $X i$ stand for number of size fractions, proportion of the $i$ size fraction, and mean diameter of the $i$ sieve opening (mm), respectively (Kemper and Rosenau, 1986).

\section{Statistical analysis}

The data were statistically analyzed with one-factor of ANOVA in SAS software, and the Duncan's multiple range test was used to compare the significant differences between the treatments at $P<0.05$.

\section{RESULTS AND DISCUSSION}

\section{Mycorrhizal status}

There was no root AM colonization and soil hyphal length in trifoliate orange subjected to the $\mathrm{TO}^{-} / 37 \mu \mathrm{m} / \mathrm{TO}^{-}$treatment. However, when the trifoliate orange seedlings as the donor were inoculated with $P$. occultum, root AM colonization of the donor plant was $37.66 \pm 1.84$ and $58.66 \pm 1.79 \%$ under the separation of 37 and $0.45 \mu \mathrm{m}$ conditions, and root AM colonization of the corresponding receptor plant was $30.36 \pm 2.22$ and $0 \%$, respectively. Our study also indicated that the soil hyphal length ranged from $10.3 \pm 0.9$ to $30.6 \pm 2.0$ $\mathrm{cm} / \mathrm{g}$ soil in donor plant inoculated with $P$. occultum under the separation of 37 and $0.45 \mu \mathrm{m}$ conditions, and extraradical mycelium could pass through the $37 \mu \mathrm{m}$ mesh but not the $0.45 \mu \mathrm{m}$ mesh under the $\mathrm{TO}^{+} / 37 \mu \mathrm{m} / \mathrm{TO}^{-}$conditions (Fig. 1), resulting in $10.3 \pm 0.9 \mathrm{~cm} / \mathrm{g}$ soil in rhizosphere of receptor plant under separation of $37 \mu \mathrm{m}$ mesh. Moreover, the root of the receptor plant under the $\mathrm{TO}^{+} / 37 \mu \mathrm{m} / \mathrm{TO}^{-}$ condition was colonized by the extraradical mycelium of the donor plant, further indicating that a CMN established between the seedlings from two compartments of a rootbox.

\section{Biomass production}

The present results showed that inoculation with $P$. occultum significantly increased the production of leaf, stem, and root fresh weight in donor plant, irrespective of separation with 37 or $0.45 \mu \mathrm{m}$ mesh (Table 1), which agrees with the results of Wu et al. (2013b) in different citrus genotypes. Our results also indicated that the extraradical mycelium of the donor plant could pass through $37 \mu \mathrm{m}$ but not $0.45 \mu \mathrm{m}$ mesh to increase leaf, stem, and root fresh biomass of the receptor. Interestingly, when rice as a donor was inoculated with $F$. mosseae, the CMN only improved plant dry weight of the receptor rice, but not the receptor watermelon (Ren et al., 2013). This growth improvement in receptor plant caused by $\mathrm{CMN}$ may be due to $\mathrm{P}$ transfer from donor to receptor (Li et al., 2004). Tuffen et al. (2002) found that CMN established between leek plants, while did not affect plant growth of the receptor. This may ascribe to the differences in CMN types induced by AMF, the receptor plant genotypes used, and growth substrates (Drew et al., 2006), after all there is an existence of compatibility between donor and receptor plants caused by CMN (Xu et al., 2012). Our study also indicated that leaf, stem, and root biomass of the receptor plant under $0.45 \mu \mathrm{m}$ conditions was profoundly decreased, compared with the receptor plant treated by $\mathrm{TO}^{-} / 37 \mu \mathrm{m} /$ $\mathrm{TO}^{-}$or $\mathrm{TO}^{+} / 37 \mu \mathrm{m} / \mathrm{TO}^{-}$. Possibly, the $0.45 \mu \mathrm{m}$ mesh prevents the part underground substrate communications between donor and receptor plants, resulting in the growth decrease of the receptor plant.

\section{GRSP production}

In the rhizosphere of the donor plant, the AMF inoculation significantly increased EE-GRSP, DE-GRSP, and T-GRSP

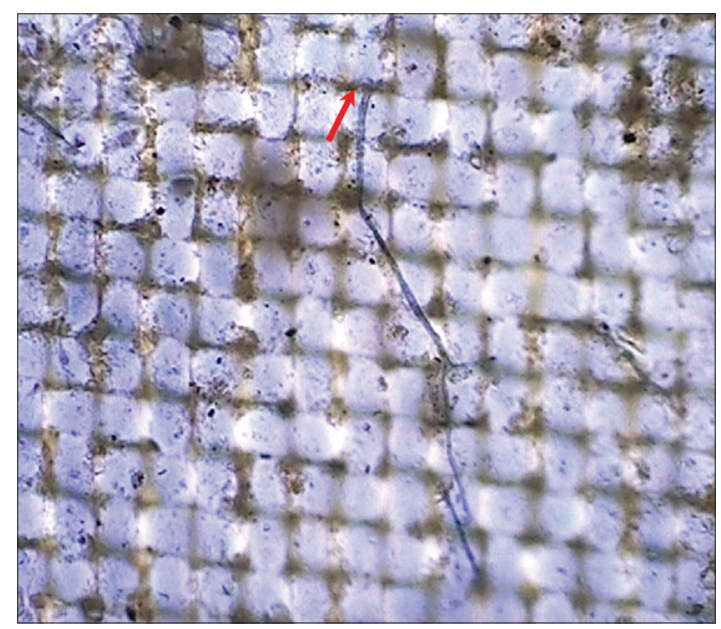

Fig 1. Extraradical mycelium in $37-\mu \mathrm{m}$ mesh in trifoliate orange (Poncirus trifoliata) seedlings inoculated with Paraglomus occultum and grown in a two-compartmented rootbox. Red arrow shows the entry of extraradical mycelium into $37-\mu \mathrm{m}$ mesh

Table 1: Effect of a CMN on leaf, stem, and root fresh weight $(\mathrm{g})$ between trifoliate orange seedlings inoculated with Paraglomus occultum and grown in a two-compartmented rootbox separated by 37-mm or 0.45-mm mesh

\begin{tabular}{|c|c|c|c|c|c|c|}
\hline \multirow[t]{2}{*}{ Treatment } & \multicolumn{3}{|c|}{ Donor (g FW plant $\left.{ }^{-1}\right)$} & \multicolumn{3}{|c|}{ Receptor (g FW plant ${ }^{-1}$ ) } \\
\hline & Leaf weight & Stem weight & Root weight & Leaf weight & Stem weight & Root weight \\
\hline $\mathrm{TO}^{+} / 37 \mu \mathrm{m} / \mathrm{TO}^{-}$ & $2.02 \pm 0.15 a$ & $2.67 \pm 0.43 a$ & $2.41 \pm 0.04 b$ & $1.66 \pm 0.27 a$ & $2.21 \pm 0.10 \mathrm{a}$ & $2.53 \pm 0.08 a$ \\
\hline $\mathrm{TO}^{+} / 0.45 \mu \mathrm{m} / \mathrm{TO}^{-}$ & $1.78 \pm 0.48 a$ & $2.50 \pm 0.14 a$ & $2.72 \pm 0.22 a$ & $0.99 \pm 0.08 c$ & $1.14 \pm 0.07 \mathrm{c}$ & $1.57 \pm 0.06 c$ \\
\hline $\mathrm{TO}^{-} / 37 \mu \mathrm{m} / \mathrm{TO}^{-}$ & $0.95 \pm 0.05 b$ & $1.09 \pm 0.11 b$ & $1.30 \pm 0.08 \mathrm{c}$ & $1.26 \pm 0.03 b$ & $1.67 \pm 0.08 b$ & $1.90 \pm 0.09 b$ \\
\hline
\end{tabular}

Note: Different letters between treatment indicate significant differences (Duncan test, $\mathrm{P}<0.05)$. Donor: The plant inoculated with mycorrhizal fungi. Receptor: The plant inoculated without mycorrhizal fungi but infected by mycorrhizal mycelium of another inoculated plant 
concentration (Table 2), which is in agreement with the findings of Wu et al. (2014a) and Wang et al. (2014), who reported the positive contribution of AMF inoculation to the production of GRSP fractions in rhizosphere of trifoliate orange seedlings grown in pots or two-chambered rootbox. In the rhizosphere of the receptor plant, both $\mathrm{TO}^{+} / 37 \mu \mathrm{m} / \mathrm{TO}^{-}$and $\mathrm{TO}^{+} / 0.45 \mu \mathrm{m} / \mathrm{TO}^{-}$treatments significantly increased EE-GRSP and T-GRSP level, but did not alter DE-GRSP concentration, as compared with $\mathrm{TO}^{-} / 37 \mu \mathrm{m} / \mathrm{TO}^{-}$treatment. This result indicated that $\mathrm{CMN}$ under $37 \mu \mathrm{m}$ mesh condition also released GRSP fractions into the receptor rhizosphere, and GRSP might pass through $0.45 \mu \mathrm{m}$ mesh from donor to receptor

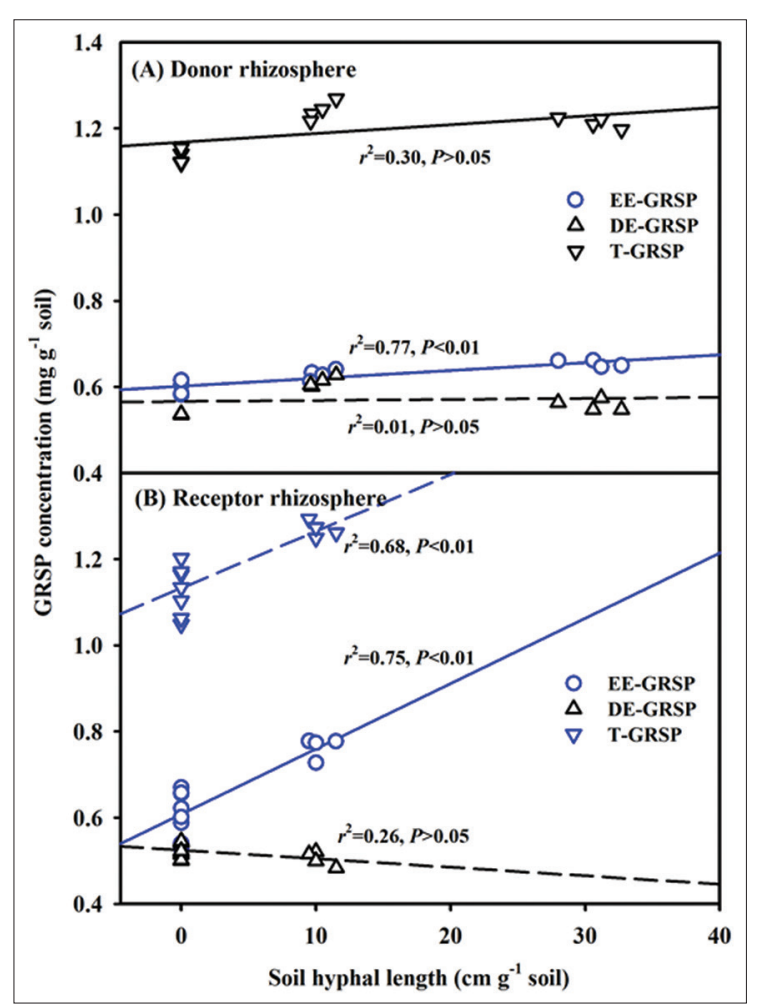

Fig 2. Linear regression between soil hyphal length and GRSP concentration in rhizosphere of donor ( $A$, the inoculated plant) and receptor $(B$, the infected plant by mycorrhizal mycelium from another inoculated plant) trifoliate orange (Poncirus trifoliata) seedlings inoculated with Paraglomus occultum and grown in a twocompartmented rootbox s eparated by $37-\mu \mathrm{m}$ or $0.45-\mu \mathrm{m}$ mesh $(n=12)$ rhizospheres. EE-GRSP is new produced glomalin and relatively active, and DE-GRSP is older glomalin and insensitive (Wu et al., 2015a). Therefore, the new and active EE-GRSP, but not DE-GRSP, was significantly positively correlated with soil hyphal length, irrespective of the donor or receptor rhizosphere (Fig. 2A, 2B).

\section{Aggregate stability}

As shown in Table 2, MWD in donor and receptor rhizosphere was significantly higher in the seedlings exposed to the $\mathrm{TO}^{+} / 37 \mu \mathrm{m} / \mathrm{TO}^{-}$and the $\mathrm{TO}^{+} / 0.45 \mu \mathrm{m} /$ $\mathrm{TO}^{-}$treatment than to the $\mathrm{TO}^{-} / 37 \mu \mathrm{m} / \mathrm{TO}^{-}$treatment. It is known that mycorrhizal hyphae played an important role in soil aggregation and stabilization (Leifheit et al., 2014). And a byproduct of AM hyphae, GRSP, can cement soil aggregates into macro-aggregates as a glue agent in soil (Rillig, 2004; Wu et al., 2013a). Correlationship analysis showed that EE-GRSP and T-GRSP were significantly positively correlated with MWD in rhizosphere of donor and receptor plant (Fig. 3A, 3B), and soil hyphal length was significantly positively correlated with MWD only rhizosphere of receptor plant (Fig. 4). Wang et al. (2015) also confirmed that exogenous EE-GRSP strongly mediated soil aggregate stability in citrus rhizosphere. As stated by Wu et al. (2014a), aggregate stability was involved in many factors, including roots, root exudates, soil hyphae, and GRSPs. In these factors, GRSPs exhibited the primary functioning in aggregate stability. However, under P stress conditions, there was not a significant correlation of EEGRSP and T-GRSP with soil hyphal length in F. mosseaecolonized trifoliate orange grown in sand (Wu et al., 2015a). This may be due to the difference of growth substrate and AMF species used.

\section{SOC}

The present study showed that SOC content in rhizosphere of trifoliate orange was significantly higher under the $\mathrm{TO}^{+} / 37 \mu \mathrm{m} / \mathrm{TO}^{-}$and the $\mathrm{TO}^{+} / 0.45 \mu \mathrm{m} / \mathrm{TO}^{-}$conditions than under the $\mathrm{TO}^{-} / 37 \mu \mathrm{m} / \mathrm{TO}^{-}$condition, irrespective of the donor or receptor plant. GRSPs not only contained aromatic (42-49\%) and carboxyl (24-30\%) C but also low aliphatic (4-11\%) and carbohydrate-type (4-16\%)

Table 2: Effect of a CMN on rhizospheric GRSP concentration, SOC concentration and MWD between trifoliate orange seedlings inoculated with Paraglomus occultum and grown in a two-compartmented rootbox separated by $37-\mathrm{mm}$ or $0.45-\mathrm{mm}$ mesh

\begin{tabular}{llccccc}
\hline $\begin{array}{l}\text { Plant } \\
\text { status }\end{array}$ & Treatment & $\begin{array}{c}\text { EE-GRSP } \\
\left(\mathbf{m g ~ g}^{-1} \text { soil) }\right.\end{array}$ & $\begin{array}{c}\text { DE-GRSP } \\
\left(\mathbf{m g ~ g}^{-1} \text { soil) }\right.\end{array}$ & $\begin{array}{c}\text { T-GRSP } \\
\left(\mathbf{m g ~ g}^{-1} \text { soil) }\right.\end{array}$ & $\begin{array}{c}\text { SOC } \\
\left(\mathbf{m g ~ g}^{-1} \text { soil) }\right.\end{array}$ & $\begin{array}{c}\text { MWD } \\
\left(\mathbf{m m}^{2}\right)\end{array}$ \\
\hline Donor & $\mathrm{TO}^{+} / 37 \mu \mathrm{m} / \mathrm{TO}^{-}$ & $0.63 \pm 0.01 \mathrm{~b}$ & $0.61 \pm 0.01 \mathrm{a}$ & $1.24 \pm 0.02 \mathrm{a}$ & $11.14 \pm 0.07 \mathrm{~b}$ & $0.48 \pm 0.02 \mathrm{a}$ \\
& $\mathrm{TO}^{+} / 0.45 \mu \mathrm{m} / \mathrm{TO}^{-}$ & $0.65 \pm 0.01 \mathrm{a}$ & $0.56 \pm 0.01 \mathrm{~b}$ & $1.21 \pm 0.01 \mathrm{~b}$ & $13.10 \pm 0.07 \mathrm{a}$ & $0.42 \pm 0.01 \mathrm{~b}$ \\
& $\mathrm{TO}^{-} / 37 \mu \mathrm{m} / \mathrm{TO}^{-}$ & $0.60 \pm 0.02 \mathrm{c}$ & $0.54 \pm 0.00 \mathrm{c}$ & $1.13 \pm 0.02 \mathrm{c}$ & $8.46 \pm 0.03 \mathrm{c}$ & $0.39 \pm 0.01 \mathrm{c}$ \\
& $\mathrm{TO}^{+} / 37 \mu \mathrm{m} / \mathrm{TO}^{-}$ & $0.76 \pm 0.02 \mathrm{a}$ & $0.51 \pm 0.02 \mathrm{a}$ & $1.27 \pm 0.02 \mathrm{a}$ & $11.36 \pm 0.20 \mathrm{a}$ & $0.62 \pm 0.02 \mathrm{a}$ \\
Receptor & $\mathrm{TO}^{+} / 0.45 \mu \mathrm{m} / \mathrm{TO}^{-}$ & $0.65 \pm 0.02 \mathrm{~b}$ & $0.53 \pm 0.02 \mathrm{a}$ & $1.18 \pm 0.02 \mathrm{~b}$ & $10.78 \pm 0.07 \mathrm{~b}$ & $0.42 \pm 0.01 \mathrm{~b}$ \\
& $\mathrm{TO}^{-} / 37 \mu \mathrm{m} / \mathrm{TO}^{-}$ & $0.56 \pm 0.04 \mathrm{c}$ & $0.52 \pm 0.02 \mathrm{a}$ & $1.09 \pm 0.04 \mathrm{c}$ & $9.66 \pm 0.05 \mathrm{c}$ & $0.40 \pm 0.01 \mathrm{~b}$ \\
& & &
\end{tabular}

Note: Different letters between treatment indicate significant differences (Duncan test, $\mathrm{P}<0.05)$. Donor: The plant inoculated with mycorrhizal fungi. Receptor: The plant inoculated without mycorrhizal fungi but infected by mycorrhizal mycelium of another inoculated plant 


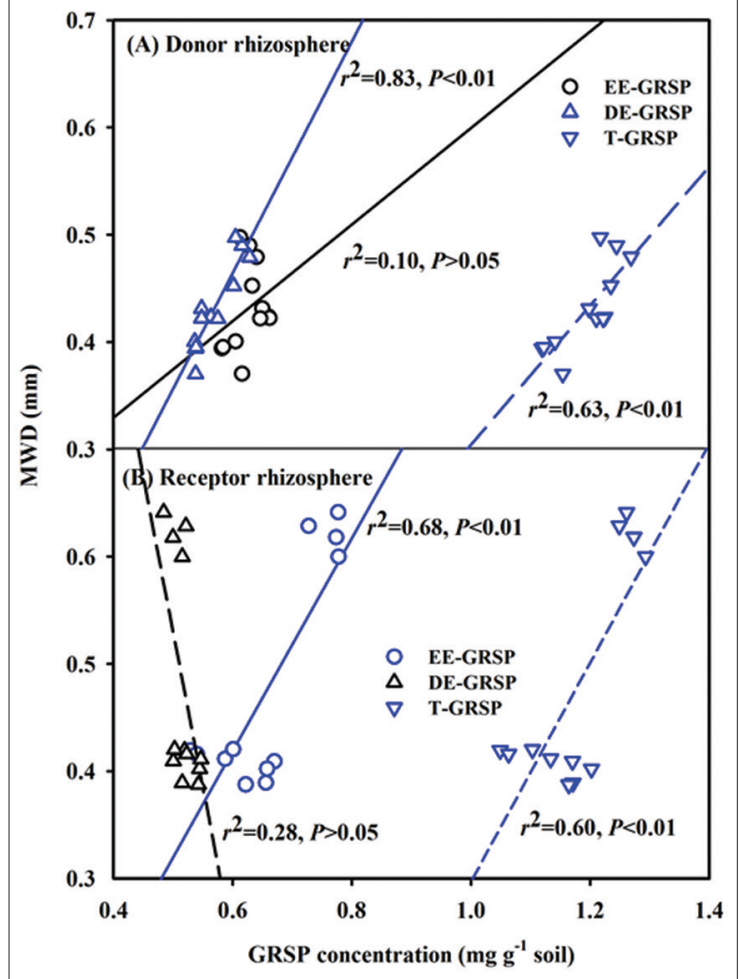

Fig 3. Linear regression between GRSP concentration and MWD in rhizosphere of donor ( $A$, the inoculated plant) and receptor $(B$, the infected plant by mycorrhizal mycelium from another inoculated plant) trifoliate orange (Poncirus trifoliata) seedlings inoculated with Paraglomus occultum and grown in a two-compartmented rootbox separated by $37-\mu \mathrm{m}$ or $0.45-\mu \mathrm{m}$ mesh $(n=12)$.

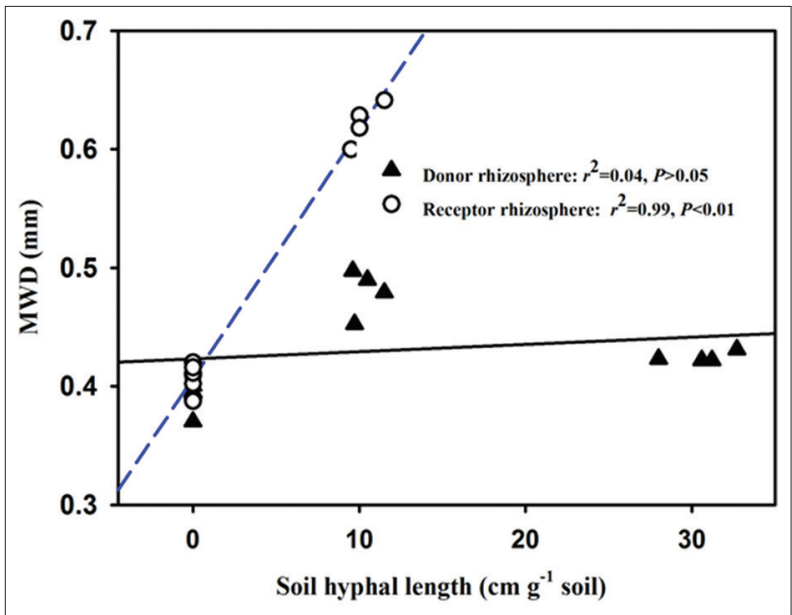

Fig 4. Linear regression between soil hyphal length and MWD in rhizosphere of donor (the inoculated plant) and receptor (the infected plant by mycorrhizal mycelium from another inoculated plant) trifoliate orange (Poncirus trifoliata) seedlings inoculated with Paraglomus occultum and grown in a two-compartmented rootbox separated by $37-\mu \mathrm{m}$ or $0.45-\mu \mathrm{m}$ mesh $(n=12)$

C contents (Schindler et al., 2007). Moreover, GRSPs in tropical areas accounted for about $4 \% \mathrm{c}$ of total $\mathrm{C}$ in soil. In this study, EE-GRSP and T-GRSP represented significantly positive correlation with SOC (Fig. 5), suggesting that

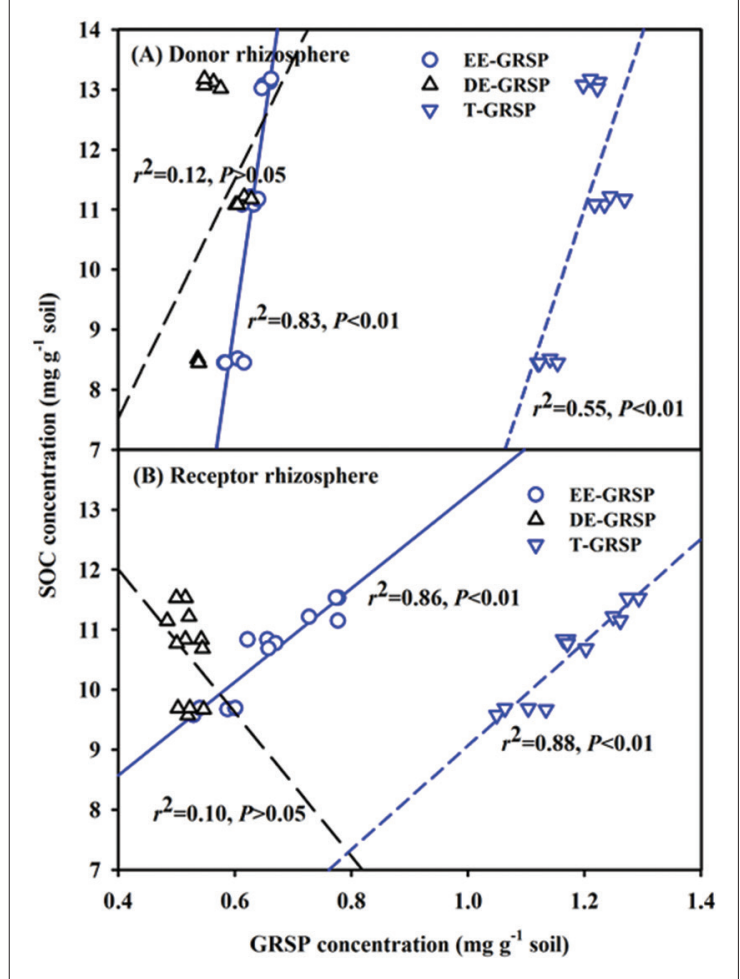

Fig 5. Linear regression between GRSP concentration and SOC concentration in rhizosphere of donor ( $A$, the inoculated plant) and receptor $(B$, the infected plant by mycorrhizal mycelium from another inoculated plant) trifoliate orange (Poncirus trifoliata) seedlings inoculated with Paraglomus occultum and grown in a twocompartmented rootbox separated by $37-\mu \mathrm{m}$ or $0.45-\mu \mathrm{m}$ mesh $(n=12)$

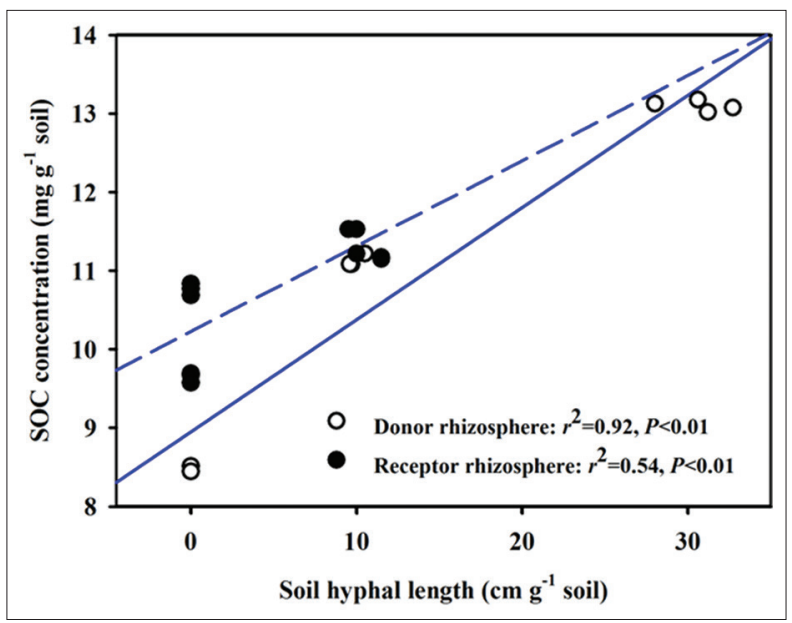

Fig 6. Linear regression between soil hyphal length and SOC concentration in rhizosphere of donor (the inoculated plant) and receptor (the infected plant by mycorrhizal mycelium from another inoculated plant) trifoliate orange (Poncirus trifoliata) seedlings inoculated with Paraglomus occultum and grown in a two-compartmented rootbox separated by $37-\mu \mathrm{m}$ or $0.45-\mu \mathrm{m}$ mesh $(n=12)$

GRSP positively contributed soil C pools. Moreover, soil hyphal length was significantly positively correlated with SOC concentration in rhizosphere of donor and receptor (Fig. 6). Wang et al. (2014) also showed that AMF-induced 
SOC alteration was dependent on AMF species. SOC as an important component of the soil fertility, is the core of soil quality and function (He et al., 2011). Therefore, AMF inoculation and subsequent $\mathrm{CMN}$ formation may take part in the contribution to soil fertility.

\section{CONCLUSIONS}

This study firstly confirmed the CMN presence between trifoliate orange seedlings under $P$. occultum inoculation condition. The CMN also colonized the roots of the receptor plant under separation of $37-\mu \mathrm{m}$ but not $0.45-\mu \mathrm{m}$ mesh, inducing a moderate root AM colonized level in the receptor plant, which significantly increase rhizospheric EE-GRSP, T-GRSP, SOC, and MWD in receptor plant, but considerably inhibited biomass production of receptor plant. Our results suggested that AMF inoculation and the subsequent $\mathrm{CMN}$ establishment benefited to improvement of plant growth and rhizospheric soil aggregation and fertility in donor and receptor plant.

\section{ACKNOWLEDGEMENTS}

This research was supported by the Citrus Modern Industrial Technology System in Hubei and the Open Funding of Institute of Root Biology, Yangtze University (R201401).

\section{Author contributions}

Y.X. Y, Q.S. W and S.K. Y. designed the study. Z.Z. Z, L. J, C.L. L, F.Y. S and X. P and took the data. Y.X. Y, Y.G. L and Z.Z.Z did the data analysis and wrote this paper. S.K. $Y$ supervised the research project.

\section{REFERENCES}

Bainard, L. D., J. N. Klironomos and A. M. Gordon. 2011. Arbuscular mycorrhizal fungi in tree-based intercropping systems: A review of their abundance and diversity. Pedobiologia. 54: 57-61.

Barto, E. K., J. D. Weidenhamer, D. Cipollini and M. C. Rillig. 2012. Fungal superhighways: do common mycorrhizal networks enhance below ground communication? Trends. Plant Sci. 17: 633-637.

Bethlenfalvay, G. J. and R. N. Ames. 1987. Comparison of two methods for quantifying extraradical mycelium of vesiculararbuscular mycorrhizal fungi. Soil Sci. Soc. Am. J. 51: 834-837.

Buscardo, E., S. Rodriguez-Echeverria, L. Barrico, M. A. Garcia, H. Freitas, M. P. Martin, P. D. Angelis and L. A. H. Muller. 2012. Is the potential for formation of common mycorrhizal networks influenced by fire frequency? Soil Biol. Biochem. 46: 136-144.

Cruz, A. F., T. Ishii, I. Matsumoto and K. Kadoya. 2003. Evaluation of the mycelial network formed by arbuscular mycorrhizal hyphae in the rhizosphere of papaya and other plants under intercropping system. Braz. J. Microbiol. 34: 72-76.

Drew, E. A., R. S. Murray and S. E. Smith. 2006. Functional diversity of external hyphae of AM fungi: Ability to colonise new hosts is influenced by fungal species, distance and soil conditions. Appl. Soil Ecol. 32: 350-365.

García-Orenes, F., A. Roldan, J. Mataix-Solera, A. Cerda, M. Campoy, V. Arcenegui and F. Caravaca. 2012. Soil structural stability and erosion rates influenced by agricultural management practices in a semi-arid mediterranean agro-ecosystem. Soil Use Manag. 28: 571-579.

He, X. L., Y. P. Li and L. L. Zhao. 2010. Dynamics of arbuscular mycorrhizal fungi and glomalin in the rhizosphere of Artemisia ordosica Krasch. in Mu Us Sandland, China. Soil Biol. Biochem. 42: 1313-1319.

Kemper, W. D. and K. Rosenau. 1986. Size distribution of aggregates. In: Klute, A., (Ed.), Methods of Soil Analysis, Part 1. Madison, ASA, Pp. 425-442.

Leifheit, E. F., S. D. Veresoglou, A. Lehmann, E. K. Morris and M. C. Rillig. 2014. Multiple factors influence the role of arbuscular mycorrhizal fungi in soil aggregation - A meta-analysis. Plant Soil 374:523-537.

Li, F., B. Xu, G. Feng, J. R. Pan and X. L. Li. 2004. The role of ectomycorrhizal fungal hyphal links in phosphorus transfer between larix kaempferi seedlings and plant growth. Acta Phytoecol. Sin. 28: 218-224.

Meding, S. M. and R. J. Zasoki. 2008. Hyphal-mediated transfer of nitrate, arsenic, cesium, rubidium, and strontium between arbuscular mycorrhizal forbs and grassed from a california oak woodland. Soil Biol. Biochem. 40: 126-134.

Nakano-Hylander, A. and P. A. Olsson. 2007. Carbon allocation in mycelia of arbuscular mycorrhizal fungi during colonisation of plant seedlings. Soil Biol. Biochem. 39: 1450-1458.

Peng, S. L., T. Guo and G. C. Liu, 2013. The effects of arbuscular mycorrhizal hyphal networks on soil aggregations of purple soil in Southwest China. Soil Biol. Biochem. 57: 411-417.

Phillips, J. M. and D. S. Hayman. 1970. Improved procedures for clearing roots and staining parasitic and vesicular-arbuscular mycorrhizal fungi for rapid assessment of infection. Trans. Br. Mycol. Soc. 55: 158-161.

Piotrowski, J. S., T. Denich, J. N. Klironomos, J. M. Graham and M. C. Rillig. 2004. The effects of arbuscular mycorrhizas on soil aggregation depend on the interaction between plant and fungal species. New Phytol. 164: 365-373.

Ren, L. X., Y. S. Lou, N. Zhang, X. D. Zhu, W. Y. Hao, S. B. Sun, Q. R. Shen and G. H. Xu. 2013. Role of arbuscular mycorrhizal network in carbon and phosphorus transfer between plants. Biol. Fertil. Soils 49: 3-11.

Rillig, M. C. 2004. Arbuscular mycorrhizae, glomalin and soil quality. Can. J. Soil Sci. 84: 355-363.

Rowell, D. L. 1994. Soil science: methods and applications. Longman Scientific and Technical, Longman Group UK, Ltd., Harlow, Essex, UK.

Schindler, F. V., E. J. Mercer and J. A. Rice. 2007. Chemical characteristics of glomalin-related soil protein (GRSP) extracted from soils of varying organic matter content. Soil Biol. Biochem. 39: 320-329.

Schweiger, R. and C. Muller. 2015. Leaf metabolome in arbuscular mycorrhizal symbiosis. Curr. Opin. Plant Biol. 26: 120-126.

Smith, S. E. and D. Read. 2008. Mycorrhizal Symbiosis, 3rd ed. Academic Press, New York.

Southworth, D., X. H. He, W. Swenson, C. S. Bledsoe and W. R. Horwath. 2005. Application of network theory to potential mycorrhizal networks. Mycorrhiza. 15: 589-595.

Tuffen, F., W. R. Eason and J. Scullion. 2002. The effect of earthworms 
and arbuscular mycorrhizal fungi on growth of and 32P transfer between Allium porrum plants. Soil Biol. Biochem. 34: 10271036.

Walder, F., H. Niemann, M. Natarajan, M. F. Lehmann, T. Boller and A. Wiemken. 2012. Mycorrhizal networks: Common goods of plants shared under unequal terms of trade. Plant Physiol. 159: 2789-2797.

Wang, S., A. K. Srivastava, Q. S. Wu and R. Fokom. 2014. The effect of mycorrhizal inoculation on the rhizosphere properties of trifoliate orange (Poncirus trifoliata L. Raf.). Sci. Hortic. 170: 137-142.

Wang, S., Q. S. Wu and X. H. He. 2015. Exogenous easily extractable glomalin-related soil protein promotes soil aggregation, relevant soil enzyme activities and plant growth in trifoliate orange. Plant Soil Environ. 61:66-71.

Wu, Q. S., M. Q. Cao, Y. N. Zou and X. H. He. 2014a. Direct and indirect effects of glomalin, mycorrhizal hyphae, and roots on aggregate stability in rhizosphere of trifoliate orange. Sci. Rep. 4: 5823.

Wu, Q. S., X. H. He, M. Q. Cao, Y. N. Zou, S. Wang and Y. Li. $2013 a$. Relationships between glomalin-related soil protein in waterstable aggregate fractions and aggregate stability in citrus rhizosphere. Int. J. Agric. Biol. 15: 603-606.

Wu, Q. S., X. H. He, Y. N. Zou, K. P. He, Y. H. Sun and M. Q. Cao.
2012. Spatial distribution of glomalin-related soil protein and its relationships with root mycorrhization, soil aggregates, carbohydrates, activity of protease and $\beta$-glucosidase in the rhizosphere of Citrus unshiu. Soil Biol. Biochem. 45: 181-183.

Wu, Q. S., Y. M. Huang, Y. Li, Nasrullah and X. H. He. 2014b. Contribution of arbuscular mycorrhizas to glomalin-related soil protein, soil organic carbon and aggregate stability in citrus rhizosphere. Int. J. Agric. Biol. 16: 207-212.

Wu, Q. S., Y. Li, Y. N. Zou and X. H. He. 2015a. Arbuscular mycorrhiza mediates glomalin-related soil protein production and soil enzyme activities in the rhizosphere of trifoliate orange grown under different $P$ levels. Mycorrhiza. 25: 121-130.

Wu, Q. S., Y. G. Lou and Y. Li. 2015b. Plant growth and tissue sucrose metabolism in the system of trifoliate orange and arbuscular mycorrhizal fungi. Sci. Hortic. 181: 189-193.

Wu, Q. S., R. X. Xia and Y. N. Zou. 2008. Improved soil structure and citrus growth after inoculation with three arbuscular mycorrhizal fungi under drouht stress. Eur. J. Soil Biol. 44: 122-128.

Wu, Q. S., Y. N. Zou, Y. M. Huang, Y. Li and X. H. He. 2013b. Arbuscular mycorrhizal fungi induce sucrose cleavage for carbon supply of arbuscular mycorrhizas in citrus genotypes. Sci. Hortic. 160: 320-325.

Xu, L. J., Z. K. Diao, Y. Li and R. J. Liu. 2012. Eco-physiological functions of mycorrhizal fungi. Chin. J. Appl. Ecol. 23: 285-292. 